\title{
Linguistic Concordances. Case study - father in 2 languages (Romanian - Italian) and 2 dialects (Dacoromanian - Calabrian)
}

\author{
Cosmina Cosma \\ Babeș - Bolyai University, Romania and University of Calabria, Italy
}

\begin{abstract}
.
The aim of the present research is to compare the same word in two different linguistical levels and to share through this example how the language and the dialect are different. Our lexical comparison is made in base of the Latin roots and takes into account the semantic branch, as well as the onomasiological and the etymological ones. Father, individualized in the kinship lexical field, represents our research champion for the analysis. By using linguistic atlases and etymological dictionaries, we traced the evolution/stagnation/involution of this specific lemma, across the time, having, as geographical observation field, Romania and Italy. Inside those two Romance territories, we chose to emphasize the border between language and dialect through Dacoromanian and Calabrian, interpreted in a triple perspective (regional variant, subdialect, language). We meant to work with modern means of investigation, as berlinian schema, semantic matrix or lexical tables, in order to make our research both interesting and connected to the present reality.
\end{abstract}

Keywords: comparative lexicology; dialect; father; language; Romance.

\section{Introduction}

Our purpose is to analyze the word father from the lexical point of view, both synchronically and diachronically, taking into account not just the standard language, but also the dialectal perspective. The area is centered on two Romance languages (Italian and Romanian) and two dialects met on those territories. It's about the Dacoromanian dialect, formed on Dacia territory, hard influenced by the Latin and with a powerful importance for the formation of the Romanian language and the Calabrian dialect, found just in Calabria region, frequently spoken our days and also with strong Latin influences. In fact, the Latin is the main purpose that links especially the two different dialects. We projected the work in base of four steps, proposed by De Rose into his methodological research book ${ }^{1}$. We will present our paper in base of it.

\footnotetext{
${ }^{1}$ De Rose, 2003.
} 


\section{2nd world conference on research in SOCIAL SCIENCES}

\section{Object and objectives definitions}

From the theoretical perspective, our branch is a linguistical one, based on the comparative linguistic, whereas we have to deal with two different languages and two different dialects. We choose to work even with languages but also with dialects for emphasizing the fact that there is no difference between them, except the political powerful perception. In this research we implied some parameters like geographical area and the nature of the population or their specifics, because of the dialectal comparison.

The main difference that we should do in working with the concepts is the distinction between language and dialect and how they are felt in those regions. We will emphasize the contradictory definition of dialect in a gradual manner: dialect is percepted as regional variant of a language (cfr. Dîrul, 2008: 107) or one of its ramifications to which is subordinated, in other dictionaries being associated with speech/utterance/subdialect (cfr. Niculae, 2001: 28) or moreover, properly with language (cfr. Ilin, 1995: 96).

Because the definitions regarding the word dialect was not enough satisfying to clarify the difference between language and dialect, we try to make that difference from the diachronic point of view, through its evolutive sequences: superstratum or the language structures created because of the arrival of the other languages (in our case the Slavic, the Greek and the Albanese languages), adstratum that produces the quantitative changes: the development of the lexicon because of the territorial proximity (Ukrainian versus Turkish) and substratum (sublayer) with elements that entered into the Latin from the languages of the conquered population; they adopted the Latin by letting their own individualized language, the main reason being a political one: the Roman conquest. From this point of view, we have to deal with an Oriental Latin present on both territories.

Once we clarified the Latin connection, we move forward with the relationship between language and dialect. We get the dialect as language opposed to another language and this can be evaluated twice:

- as variety (different in accent, grammatical constructions and words) of the national language, where the dialects divide the same structural characteristics and the same story with the national language;

- as language, in opposition (see the difference among standard, regional, dialectal) with the national language, where dialects are considered as any other autonomous languages, with a proper territorial characterization but without political relevance and literary prestige.

Whichever interpretation would have, language and dialect do not exclude each other but they create relationships (e. g. the relationship between the linguistical varieties of Italian and Tuscany or Lazio speech). Having said that, we are talking about language - dialect relationship taking into account the mutual intelligibility criteria. In base of its main property, that analyze if the speakers are able to easily understand what the interlocutor says, without the effort of learning, the criteria that we just mentioned can be generally applied as the main principle of the historical linguistics (that see the 


\section{2nd world conference on research in SOCIAL SCIENCES}

Neolatin languages as dialects of Latin). We want to fortify the bottom line based on no difference between language and dialect even by applying some linguistical criteria: the genealogical one, where the convergence of the languages is primordial (one unique variety has the ability to discern from two distinct varieties) and the waves theory, where the linguistical changes are spreading from main centers to the marginal areas, the aim being the intersection and not the time or place. In both cases we have a type of sociolinguistic code - switching in which the standardization produces a standard language where dialects or non - standard varieties were before, under dimension and prestige variables. In base of this perception, we propose the following schema:

Figure 1: Dacoromanian and Calabrian from their beginnings
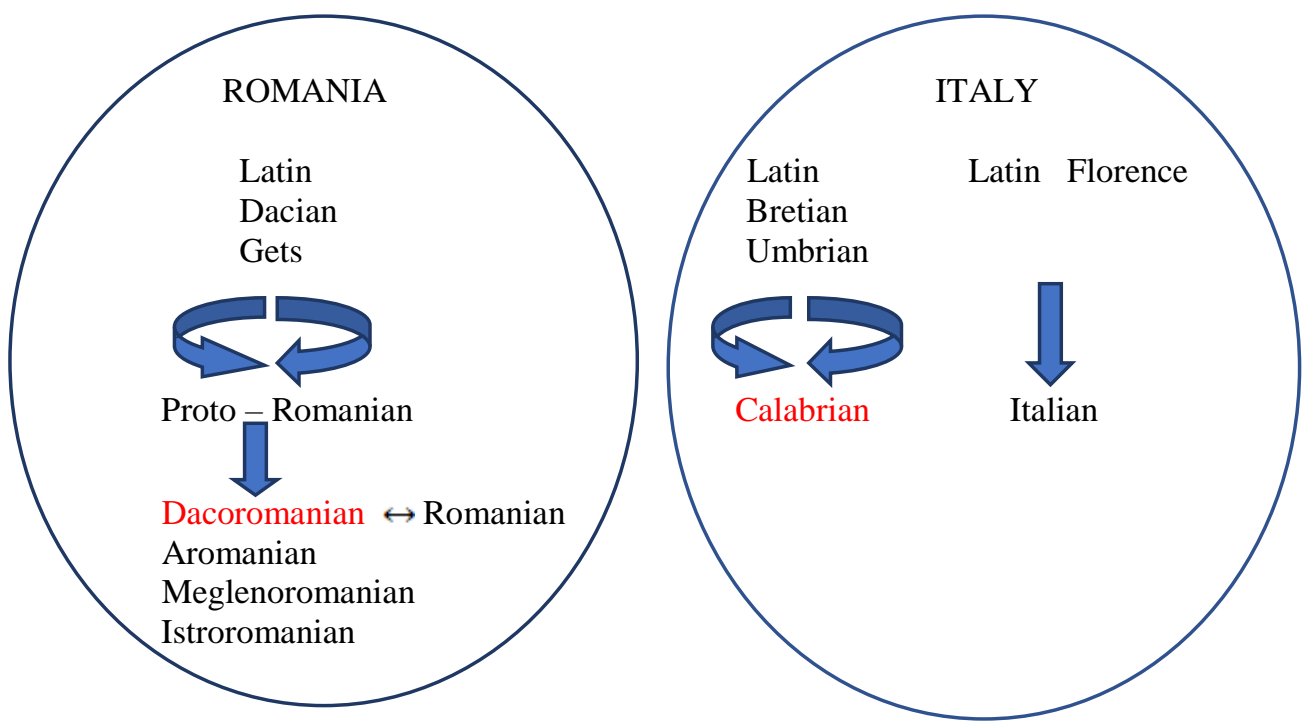

The theoreticians that support the relationship between Romania and Italy and its connection with Latin are Rossetti, 1978: 78 (the Romanian language is the Latin language spoken in the oriental part of the Roman Empire) and Pușcariu, 1976: 183 (the Romanian language is the Latin spoken in 1939, with the emerged modifications during the centuries) or Giacomo, 1991 (that distinguishes two areas of Calabria, in base of the relationship with Latin: those that accept and modify the Latin and those one that accept the Latin, without letting notable changes) and Rohlfs, 1972 (that divides also Calabria in two areas, in base of Latin influences - the South part and Greek dominance - the North part). There were notable names that observed also the relationship between Romania and Calabria, even if the report is from country to region. For example, Bartoli, 1945 places the Romanian together with Italian dialects from the Adriatic coast, Griera, 1922, Wartburg, 1936 and Herman, 1987 goes beyond by associating the Romanian just with the Southern dialects of the other territory and Nichita, 1984 makes an analogy properly with the Dacoromanian and the meridional dialects of Italy.

Another category of theorists (except those one that favorize the similarity of Romania with the South part of Italy) are the scientists that claims for the archaicity of Romania and Italy. Even if the specialized literature sustains a percentual of 23,5\% 


\section{2nd world conference on research in SOCIAL SCIENCES}

for the representative vocabulary of Romania and $12 \%$ for Italy, Sala, 1988 progresses, by associating with Latin nearly a half of the Romanian words: $30,33 \%$ from the Latin background and 15,26\% originating from savant Latin. Calabria has still a score of almost $50 \%$ of Latin words, cfr. Rohlfs, 1972. These results were directed for choosing the lexical field, the hypothesis being not even the history/latinity of the words, but also the mother - tongue descendent for both territories. In this respect, the etymological reconstruction comes to complete the linguistical conservativity and also it checks if in those conservative areas the significance of a word is able to produce changes/there is no change of significant. Otherwise, the lexicology is the field that has in his content the evolution/involution/stagnation of the words. The lemmatical reconstruction implies both sense (that has to deal with semantics and onomasiology, as branches of linguistics) and origin (etymology), that is not just sense but also sense development, in different historical phases. And this history of the word can be realized through the comparative lexicology, chosen as main method for the present research. Thereby, etymology is that one that makes the difference between lexicon and vocabulary (that takes into account just the semantic element), not so pronounced nowadays, because the first one regards the sense but also the sense into its different stages of evolution.

In what follows we will do a description of the word father that belongs to the kinship lexical field, in base of some factors that will emphases tree different possibilities: the presence of the same format of the word, the change of the Latin etymon/ word structure or its conservative form. We also tried to avoid some problems that appeared when we dealt with the following factors:

- frequency: regards the most used words, the context of using and if they are employed in the language, into the dialect or in both linguistical areas. The problem is understood in terms of used/non used words, in a simplifying tendency;

- stylistic - functional factor: has to deal with the economy of words in everyday language and their short forms, diminutives or augmentatives. The main problem that can appear here is the tendency of reducing the word;

- psychological factor: is responsible for the contexts in which the words are applied, the decision of using or not using a word being expressed in terms of where, when and how to utilize a specific lemma. The three rhetorical questions are constituent for the main problems on here;

- semantical one - regards the change of meaning that the word can have, its development or contrariwise, its limitation, being determined and personally modified, from one culture to another (e. g. the different type of white for the Eskimo). The lack of knowledge for a specific culture and, in consequence, the lack of knowing the entire word, can cause a problem;

- etymological factor that implies both the origin and the evolution or deviation of the words, where the analysis is divided in base of the presence of the same format of the word, from the beginning to the present time, the change or the maintenance of the Latin etymology. The problems are not the simple or the complete etymologies but the complex ones, that presents themselves as mini - monographies that can have, from a certain point, more etymologies. For 


\section{2nd world conference on research in SOCIAL SCIENCES}

being more faithful to the etymology, we choose a field with a well - known content in all languages or dialects: the kinship.

As main sources we were using documents like linguistical atlases ALR I, II for Romania and ALI VIII for Italy, both with linguistic material grouped in base of family semantical category or etymological dictionaries, such as:

- Diez, 1964 and REW, 1924 for the Romance languages covering;

- Candrea - Densușianu, Chivu, 1992, Crăcea, 2007, DECA, DER (I), DLR (2013), DVL, Guțu mic, Ilin, 1995, Pușcariu, 1905, Stanciu, 1995, for Romanian area;

- DEI, DELI, De Mauro, 2000, Georges - Calonghi, GRADIT, Il Garzanti, Piangiani, 1937, VEI, for Italian area;

- Cihac, 1978, DAR II, GR, Marin, 2010, Mărgărit, 2009, Popescu - Sireteanu, 2013, REG II, for Dacoromania and Acattatis, 1977, Cotronei, 1986, DEDI, Malara, 1982, Martino, 2010, Marzano, 1928, Matta, 1998, Mossiano, 1985, Pisano, 2011, Rohlfs, 1968, 2010, Scerbo, 1886, for Calabria.

\section{Operational planning}

As part of the operational planning is the methodological choice consisting, in our case, in the work with the comparative lexicology. The analysis of the word had in its component, elements that regards non just the semantic branch but also the etymological (concentrated on the evolution of the meaning) and onomasiological one (interested moreover into the form of the word). Moving out from one specific idea, the comparative lexicology examines the ways through it can be expressed in many languages or dialects, related or cultural related, the kinship phenomenon. The linguistic context is dealing with the sociology and gets into its internal structure of the speech introspective methods and quantitative studies that shows historically, the influence that one specific item can have. The most interesting aspect of the linguistical context is the problem of the lexical differences that frequently doesn't depend on the syntactical properties (we take into account a lonely word and not a block).

The phonetical change can defend itself gradually, from the diachronically point of view, through the lexicon of the language (cfr. Labov, 1994). Nevertheless, Milroy, 1978 sustains that some words are pronounced with major/minor coherence, from different dimensions of the population. In this respect, the lexical diffusion theory reflects the changes produces by the lexicon, because this changes spreads both across the lexicon (e. g. a new pronunciation) and population (that actually represents the speakers), in a simultaneous but different way, from one culture to another, from one region to another, from one speaker to another. For verifying how/in which measure one word is or is not assimilated, the implication scale was used (e. g. the vocalic assimilation occurrence).

The methodological question regards more processes. First of all, we individualized the lexical field and from this point of view, the word father was included into the kinship category. Next to the selection of the lexical field is the 


\section{2nd world conference on research in SOCIAL SCIENCES}

recognition process or the identification, in base of the socio - lexical reconstruction. The anthropological concept proposed by Strauss since 1949 shows, in our case, that both Romanian and Italian has the same level, vertically and horizontally. To be aware of this, we compared the two languages with English:

Figure 2: The anthropological interpretations of «father» in Italian, Romanian and English
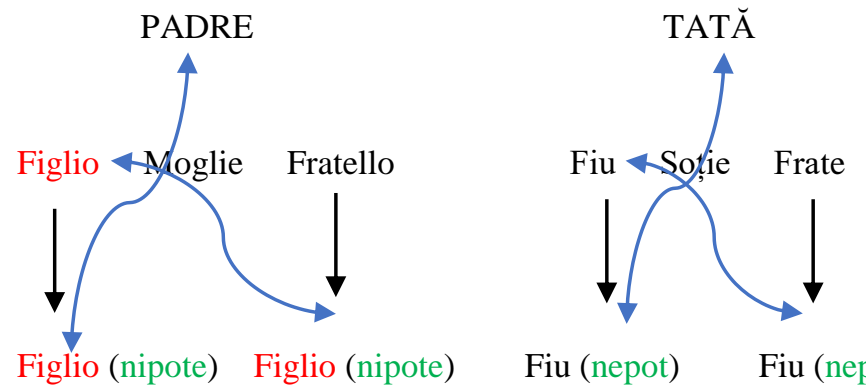

Fiu (nepot)
Fiu (nepot)

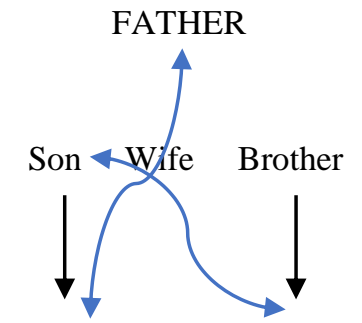

Son (grandson) Son (nephew)

Once we realized that we have to compare the same languages both on the syntagmatic and paradigmatic axis, we were sure that our analysis is correct from the methodological point of view, whatever will be the strategy adopted. At this point, we have chosen to deal with three different interpretations:

- the lexical table - in which are included all the forms of the word father from the two languages and the two dialects, but also all the lexical - semantical differences that we met inside the dictionaries and atlases. We started from the Latin term, considered generic, for continuing with the specific terms (Romanian and Italian) and the dialectal ones (Dacoromanian and Calabrian), perceived as synonyms for the generic terms and, as second choice, for the generic lemma. The main idea of this method is not limited to the etymology (well known in this case), but it is also a problem of cognitive and semantic order, having, as a starting point, the ethnical in the present time;

- the berlinian schema comes in the help of the lexical table by offering a classification of a unique lemma through the analyze on its different levels of the language: generic (characterized by the standard language), intermediate (language variety), specific (dialect) and varietal (dialect variety). This method is known by specialists as cross - classification. The present schema develops as a tree, where every level emphasizes a certain dialectal variety. The sequence of the tree is randomly constructed, being useful just for having an ordered view of the word development. With the help of this method, we were able to observe that the same word can have different Latin etymologies, some of them able to be in concomitance, from the chronological point of view (see, for example, the classical Latin vs the popular Latin);

- the semantical matrix comes to summarize the two methods in terms of binary features. Otherwise, starting from a similar position, we had the possibility to deal with cases unpredicted in theory, that obviously should not be ignored. The interpretation of the meaning, etymology and place is designed in terms of 


\section{2nd world conference on research in SOCIAL SCIENCES}

variables, where the presence $(+)$ /the absence (-) are mutually exclusive and express a gradual presence $( \pm)$ or a dominant position $(++)$. This interpretation regards not only the Latin etymology but also the Greek and the Slavic one, those predominant etymologies on the two territories. Otherwise, we were interested in the speaking evolution, having as point of reference the Latin (the description of the word before/after/in the Latin period) and in its comportment nowadays (literary or dialectal usage).

As research instruments we were using mainly etymological dictionaries (because the Romance area begins with the idea of a Latin already formed). If the etymological ones were not sufficient, we were making reference to the ordinary dictionaries or anthologies. Except dictionaries, we were using the phonetical information found inside the linguistical atlases. Beside the transcription from the phonetic into semantic information (founded inside of a specific question marks from the interview), we dealt with information divided in base of the linguistic geography, absent in the first type of resources. Hence, the available resources are not only historical, temporal, but also geographical. The list with all the documentation is emphasized at the references category.

The observation field is, on one hand, the Calabrian and Dacoromanian dialects as linguistical base, and Romanian/Italian languages with their own varieties, on the other hand. Otherwise, the sample consists of the lexical field that is well individualized: the kinship.

\section{Data collection}

Data collection consists in the observation of the data that we have found in the resources which we talked about at the previous section and their processing through the methods, described at the same section. In base of what we mentioned, we have the following results, materialized into the lexical table, berlinian schema and semantic matrix, where we were using both linguistic atlases and etymological dictionaries:

Table 1: Lexical table

\begin{tabular}{|c|c|c|c|}
\hline $\begin{array}{l}\text { Generical term } \\
\text { (Latin) }\end{array}$ & $\begin{array}{l}\text { Specific term } \\
\text { (It./Ro.) }\end{array}$ & $\begin{array}{l}\text { Author } \\
\text { (source) }\end{array}$ & $\begin{array}{l}\text { Dialectal term } \\
\text { (It./Ro.) }\end{array}$ \\
\hline \multirow[t]{2}{*}{ PATER } & padre & $\begin{array}{l}\text { ALI } \\
\text { NavigAIS } \\
\text { Martino, } 2010 \\
\text { Rohlfs 1968, } 2010\end{array}$ & $\begin{array}{l}\text { patrile, papà, tata, } \\
\text { utata, tà } \underline{\text { teto }}\end{array}$ \\
\hline & tato & $\begin{array}{l}\text { ALR } \\
\text { ALRM } \\
\text { DER } \\
\text { REG II }\end{array}$ & $\begin{array}{l}\text { tata, tete, tatuca, } \\
\text { tătuta, tatica, } \\
\text { tatune/ tatine, nene }\end{array}$ \\
\hline
\end{tabular}




\title{
2nd world conference on research in SOCIAL SCIENCES
}

19-21 March, 2021

\author{
Budapest, Hungary
}

As we can see from the lexical table, even if the two languages have a different root, the explanation for founding the Romanian form tata and its derivatives in both dialects can be explained in base of the maintenance of the Latin TATA. We underlined the Calabrian forms that were identical with the Dacoromanian ones.

Figure 3: Berlinian schema

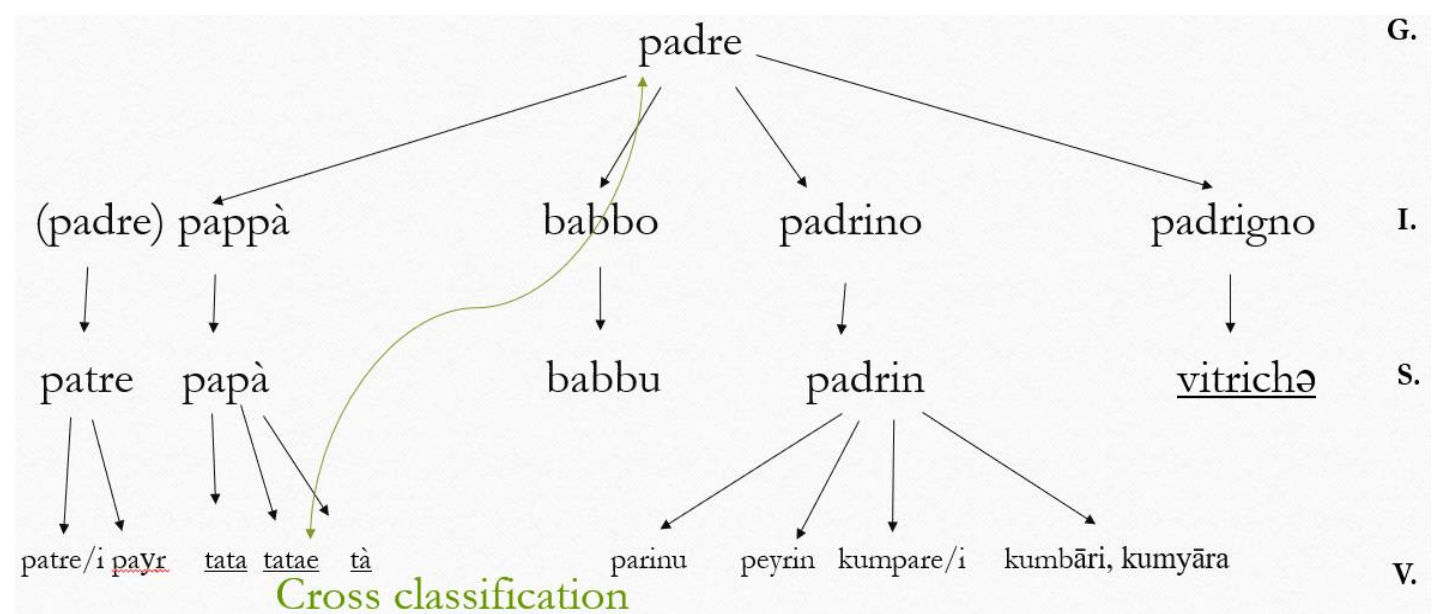

Inside the berlinian schema we can observe the development of our lemma inside ALR I and ALI VIII into more segments that shows at the last level the dialectal forms that the word father can have in Calabria. We underlined the forms that we found in Romanian language (tata, vitreg) but also in Dacoromanian dialect (tata, tatae, ta, vitric(ว), vitrig(a)). Taking into account the fact that Dacoromanian produces just phonetic different exists in contrast with the standard language (that doesn't happen with Calabrian vs Italian) we considered unnecessary a similar schema for the Romanian territory.

We were describing the main lexical exits of father in a synthetic way, by reuniting all the information that we found inside the dictionaries into a semantic matrix.

Table 2: Semantic matrix 


\begin{tabular}{|c|c|c|c|c|c|c|c|c|c|c|}
\hline \multirow[t]{3}{*}{ Word } & \multicolumn{3}{|c|}{ Etymology } & \multicolumn{3}{|c|}{ Meaning development } & \multicolumn{4}{|c|}{ Behaviour } \\
\hline & Lat. & Gr. & Sl. & before & Latin & after & Liter & use & Dia & l use \\
\hline & & & & & & & Yes & No & Yes & No \\
\hline Padre & ++ & & & + & + & + & ++ & & - & \\
\hline Pappà & + & & & & + & & ++ & & + & \\
\hline Papà & + & & & & + & & \pm & & + & \\
\hline Tata & + & & & & + & & - & + & $t$ & \\
\hline
\end{tabular}

At the beginning of the description of the word father, ALI's map sends to the comparison with the map 151 from ALR I (correspondent at Parents) and $129-130$, ALR II. We were moving forward by looking even at the map 152, ALR I, called properly Father and similarly to the maps 153 and 154 that makes reference also to this lemma: (Step)father respectively Step father. Regarding ALR II, inside the annex 2619 of the maps $129-130^{2}$ (My man/My woman) we had the representation of tătâne, that reflects moreover the generical term parent or ancestor than the sepcific one father.

By comparing the two atlases, we observed that while the questions for ALR are inside the maps, ALI presents a different method by reuniting the questions separately, into questionaries, the map 805 having just the answers related to the inquiries. We have noticed also the predominance of some words inside the maps that we were looking for. On the Italian territory the words derrived from the classic Latin PATER enter in competition with those that have the popular Latin TATA root, while in Romania the $387^{3}$ geographical points present more or less the same linguistical exits, described in base of the head - word tata. We noticed also some Calabrian areas that prefer to use both forms into their speaking. It is the case of Papasìdero, Castrovìllari, Altomonte, Crosìa, Bisignano, Longobucco, Fiume Bruzio, Falerna and Petronà. As we can observe, the mixture is all over the Calabrian territory and doesn't take into account the Greek influences from the Mediterranean part or the Latin ones, preponderant moreover at the border with Puglia region.

We were summarizing in Fig. 4 all the information that we have found inside the linguistical maps by putting together generical, phonological and phonetical

\footnotetext{
${ }^{2}$ By contrast with ALR I, ALR II presents two maps in the same time, usually in male - female pairs.

${ }^{3}$ From the whole number, $01-013$ are parts from other dialects then Dacoromanian, from which we didn't consider them for our interpretation.
} 


\title{
2nd world conference on research in SOCIAL SCIENCES
}

19-21 March, 2021

\author{
Budapest, Hungary
}

information around the word father and by taking into account the concordances that we have found in both territories:

Figure 4: abstract from the linguistical atlases interview (ALR I, ALI VIII)

How do you say «father»?

Prototypical form (arhilexeme): tata

Other forms: /ta/, /tătîn/, /tătuc/

- Differences between the speakers: [t(t)a(ta/ə)], [tətjn(e)], [tətuc(ə)], [(tə)tuts(ule)]

\section{Analysis and interpretation}

On the last stage of our research, we proposed to make an interpretation about the results that we exposed in the previous section, in base of the componence that a word lexically should have. On this purpose, we started with the semantical point of view.

After consultancy of the bibliography, we conclude about the semantical characterization of father in the following manner: parent and other words affiliated with it (grandfather, step father, father-in-law, cfr. Cihac, 1870: 279, 403 - 404, Ciobanu, 1995: 371, DE: 298, 307, DEI IV (Me - Ra): 2718 and V (Ra - Zu): 3730 3731, DELI IV (O - R): 860 - 893, DLR, Tomul XVI (T): 67 - 69 and Tomul XVIII (V): 694 - 697, Marin, 2011: 302 - 303, Piangiani, 1937: 959, Rohlfs, 1968, vol. III: 235, Scriban, 2013: 1300, VEI: 713 - 743). A different meaning has the appellative to the divinity (before having the sense of nurturer, father was utilized as synonym for senator, hero or even God, cfr. DELI IV (O - R): 880, De Mauro, 2000: 1736, Marzano, 1928: 310) or the colloquial way of using the same word: father is a name that an ordinary person can achieve in sign of respect (cfr. Marin, 2010: 303, Martino, 2010: 1185, Marzano, 1928: 432 - 433). We found some of these meanings (e. g. father used instead of stepfather or grandfather) inside the linguistical interviews from the maps 152, 153 (ALR I) and 805 (ALI VIII).

Taking into account the same dictionaries, from the onomasiological point of view, the associations were made in base of modifiers (e. g. tătâne, tată bun/mare/moș, padastro, patrigno, padrino), diminutives or augmentatives (e. g. tătucăa, tătuță, tătic( $\breve{a})$, padricello, padricciuolo or padrino), viewed as endearment formula, if the identical meaning is kept (the same explanation is made for tătâne), geographical components (the inside of which are all the dialectal words, including

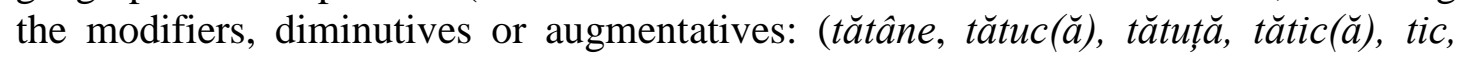
moș, tată bun/mare/moș, patrile, pà/papà, tà, tat/a, o, tatameu, tatamău, tatarjari, patrino, vitricho), cultural components (e. g. the different use of vitreg in both territories or the importance of the paternal figure inside the family: padre di famiglia/tată de familie seen as capo famiglia/cap de familie - one who manages the entire family, the motivation being a sacramental one).

For the collection of the terminology have been carried out etymological researches (via etymological ordinary or dialectal dictionaries), divided from the bibliographical point of view either in base of the etymological aspect (dialectal etymological dictionaries) then geographical (linguistic atlases relevant for the kinship lexical field). Given the limitation of the present paper, we did not think it 


\section{2nd world conference on research in SOCIAL SCIENCES}

was necessary to present all the dialectal data, collected during our various investigations and researches, that's why we will limit our exposure on the most significant data in the area concerned. In Italian language, padre comes from the classical form PATER, while the Romanian language and the two dialects, adopt the popular Latin form TATA ${ }^{4}$, in concurrence with PAPA, that produce lexical outcomes just on the Italian territory ( рарpa or papà). The Latin form BABUS that generates babbo in the regional Italian talking, explains also the association of bun/mare/moș (appellatives destinated to denominate the grandfather) with father.

If we imply the variable with which father could make a copy, we have the Latin form PARĚNTEM for both territories. We were not considering these outputs because the Italian parente (translated in English with relative) is far for the initial meaning that Romanian was keeping in părinte (Eng. parent).

\section{Conclusions}

Taking into account the whole panorama, the relationship between the Calabrian dialect and the Romanian language (that automattically includes also the Dacoromanian dialect) is more then obvious. The survey of the word development in those languages and dialects shows us than the balance squint towards the dialects and through our semantical, onomasiological and moreover etymological analysis we demonstrated it is not about the simple phonetical or semantical coincidences. The same Latin roots show us that we have to deal with the same language that was both spoken once on two different territories.

\section{References}

Regular bibliography:

Bartoli, M. (1945), Saggi di linguistica spaziale, Rosenberg \& Sellier, Torino.

De Rose, C. (2014), Che cos'è la ricerca sociale?, Carocci Ed., Roma.

Devoto, G. and Giacomelli, G. (1991), I dialetti delle regioni d'Italia, nuova edizione, Sansoni Ed., Firenze.

Griera, A. (1922), “Afro - ròmanic o ibero - ròmanic?”, Buttletí de dialectología catalana, vol. 10, pp. $34-54$.

Herman, J. (1987), La disparition de -s et la morphologie dialectale du latin parlé. Latin vulgaire - latin tardif : actes du $1^{\text {er }}$ colloque international sur le latin vulgaire et tardif. Pécs, 2 - 5 septembre 1985. Tübingen, Germany, pp. 97 - 108.

Labov, W. (1994), "Principles of linguistic change", Language in Society 20, vol. I, Blackwell, Oxford, pp. XIX - 641.

\footnotetext{
${ }^{4}$ The Dacoromanian form tata, kept also in Romanian language doesn't have to deal with the Slavic origin, that influences the other Occidental languages like Cech, Hungarian, Polish or Serbian, the word derived from Slavic being just a coincidence, cfr. DER: 776.
} 


\section{2nd world conference on research in SOCIAL SCIENCES}

19-21 March, 2021

Budapest, Hungary

Milroy, J. \& Milroy, L. (1978), "Belfast: change and variation in an urban vernacular", Sociolinguistic Patterns in British English, E. Arnold, pp. 19 - 36.

Nichita, I. (1984), Concordanțe între dialectele românești și celelalte limbi romanice. Tratat de dialectologie românească. Craiova, Romania, pp. 621 - 641.

Pușcariu, S. (1976), Limba română, vol. I: Privire generală, Ed. Minerva, București. Rohlfs, G. (1972), Studi e ricerche su lingua e dialetti d'Italia, Sansoni Ed., Firenze.

Rosetti, A. (1978), Istoria limbii române, vol. I, Ed. Știinţifică și Enciclopedică, București.

Sala, M. (1988), Vocabularul reprezentativ al limbilor romanice, Ed. Științifică și Enciclopedică, București.

Strauss, L. (1976), Le strutture elementari della parentela, trad. in italiano da Cirese, M., A., La Feltrinelli, Milano.

Wartburg, W. von (1936), Die Ausgliederung der romanischen Sprachräume, Niemeyer, Halle an der Saale.

Atlases:

ALI = Massorbio, L. et. al. (2008 - 2011), Atlante linguistico italiano, vol. VIII: Le età dell'uomo e la parentela, Istituto Poligrafico e Zecca dello Stato, Torino.

ALR I = Pop, S. et. al. (1942), Altasul linguistic român, partea I, vol. II: Familia, nașterea, botezul, copilăria, nunta și moartea, Otto Harrassowitz, Sibiu - Leipzig.

ALR II = Petrovici, E. et. al. (1940), Altasul linguistic român, partea II, vol. I: Familia, nașterea, copilăria, nunta, viața religioasă, sărbători, Otto Harrassowitz, Sibiu - Leipzig.

ALRM I = Pop, S. et. al. (1942), Micul atlas linguistic român, partea I, vol. II, Otto Harrassowitz, Sibiu - Leipzig.

Dictionaries:

Accattatis = Accattatis, L. (1977), Vocabolario del dialetto calabrese, parte prima: calabro-italiana, Pellegrini Ed., Cosenza.

Candrea - Densușianu = Candrea, I. - A.; Densușianu, O. (1907), Dicționarul etimologic al limbii române: elemente latine, Atelierele grafice Socec \&Comp, București.

Chivu 1922 = Chivu, G. et. al. (1922), Dicționarul împrumuturilor latino - romanice în limba română veche (1421 - 1760), Ed. Științifică, București.

Cihac 1870 = Cihac, A. (1870), Dictionnaire d'étymologie daco-romane, vol. I: Éléments latins comparés avec les autres langues romanes, Francfort, s / M., Ludolphe St. - Goar.

Cotronei 1986 = Cotronei, R. (1986), Vocabolario calabro - italiano. Prima parte: dialetto catanzarese, Arnaldo Forni Ed., Catanzaro, 1986. 


\section{2nd world conference on research in SOCIAL SCIENCES}

19-21 March, 2021

Budapest, Hungary

Crăcea 2007 = Crăcea, E. (2007), Dicționar latin - român, român - latin, Ed. Steaua Nordului, Constanța.

DAR II = Bulgăr, G. and Constantinescu - Dobrior, G. (2013), Dicționar de arhaisme și regionalisme, vol. II, Saeculum vizual, București.

DECA = Cârstoiu, I. et. al. (2004), Dicționar etimologic, Ed. Sitech, Constanța: Craiova.

DEDI = Cortelazzo, M. and Marcato, C. (1992), Dizionario etimologico dei dialetti italiani, UTET Libreria, Torino.

DEI = Battisti,C. and Alessio, G. (1975), Dizionario etimologico italiano, vol. IV (Me - Ra), V (Ra-Zu), G. Barbèra Ed., Firenze.

DELI = Cortelazzo, M. and Zolli, P. (1999), Dizionario etimologico della lingua italiana, vol. IV (O - R), seconda ed., Zanichelli, Bologna.

De Mauro, 2000 = De Mauro, T. et. al. (2000), Dizionario italiano, vol. II (N - Z), Mondatori Ed., Verona.

DER = Ciorănescu, A. (2007), Dicționarul etimologic al limbii române, ed. îngrijtă și trad. din limba spaniolă de Şandru Mehedinţi., T. și Popescu Marin, M., Ed. Saeculum, București.

DER I = Dincă, P. (2011), Dicționar etimologic român, vol. I: Cuvintele de origine dacă, Ed. Premier, Ploiești.

Diez 1864 = Diez, F. (1864), An Etymological Dictionary of the Romance Languages, Chiefly from the German (Etymologisches Wörterbuch der romanischen Sprachen), trad. in inglese di Donkin, T., C., Williams and Norgate, London: Edinburg.

Dîrul 2008 = Dîrul, A. et. al. (2008), Mic dicționar de termeni lingvistici, Academia de Științe a Moldovei, Chișinău.

DLR = Iordan, I. et. al. (2010), Dicționarul Limbii Române, Tomul XVI (T), XVIII(V), Ed. Academiei Române, București.

DLR 2013 = Scriban, A. (2013), Dicționarul limbii românești. Etimologii, înțelesuri, exemple, citații, arhaisme, neologisme, provincialisme, Ed. Saeculum, București. DSL = Niculae, A. al. (2001), Dicționar de științe ale limbii, Editura Nemira, București.

DVL = Chivu, G. (2008), Dictionarium Valachico - Latinum. Primul dicționar al limbii române, Ed. Academiei Române, București.

Georges - Calonghi = Calonghi, F. and Georges, K., E. (1936), Dizionario italiano latino in correlazione col dizionario latino - italiano, seconda ed., Rosenberg \& Sellier, Torino.

GR = Arvinte, V. et. al. (1961), Glosar regional, Ed. Academiei, București.

GRADIT = Battaglia, S. et. al. (1970), Grande dizionario della lingua italiana, vol. IV, Unione tipografico - editrice torinese, Torino.

Guţu 2012 = Guțu, G. (2012), Dicționar latin - român, ed. revăzută, Editura Humanitas, Bucureşti.

Ilin, S. et al. (1995), Dicționar practic al limbii române. Explicativ, etimologic, frazeologic și enciclopedic, Editura Floarea Darurilor, București.

Il Garzanti = Felici, L. et. al. (1993), Il grande dizionario Garzanti della lingua italiana, Garzanti Ed., Milano.

Malara 1982 = Malara, G. (1982), Vocabolario dialettale calabro - reggino italiano, Arnaldo Forni Ed., Catanzaro. 


\section{2nd world conference on research in SOCIAL SCIENCES}

19-21 March, 2021

Budapest, Hungary

Marin 2010 = Marin, M. et. al. (2010), Dicționarul graiurilor dacoromâne sudice, vol. III. Literele P - Z, Ed. Academiei Române, București.

Martino 2010 = Martino, G., A. et. al. (2010), Dizionario dei dialetti della Calabria meridionale, Qualecultura Ed., Vibo Valentia.

Marzano 1928 = Marzano, G., B. (1928), Dizionario etimologico del dialetto calabrese, Arnaldo Forni Ed., Laureana di Borrello.

Matta 1998 = Matta, R. et. al. (1998), Vocabolario cetrarese, Luigi Pellegrini Ed., Cosenza.

Mărgărit 2009 = Mărgărit, I. (2009), Vocabularul graiurilor muntenești actuale, Ed. Academiei Române, Bucureșt.

Mossiano 1985 = Mossiano, F. (1985), Glossario del calabrese antico, Longo Ed., Ravenna.

NavigAIS = Tisato, G., (2009 - 2021). Atlante Linguistico ed Etnografico dell'Italia e della Svizzera Meridionale [Online]. Available: https://www3.pd.istc.cnr.it/navigaisweb/\#.

Piangiani 1937 = Piangiani, O. (1937), Vocabolario etimologico della lingua italiana. $M$ - Z, Casa Ed. Sonzogno, Milano.

Pisano 2011 = Pisano, A. (2011), Dizionario dialettale calabrese, s.e., Nova Milanese.

Popescu - Sireteanu 2013 = Popescu - Sireteanu, I. (2013), Glosar dialectal din Bucovina și Moldova, Ed. Printis, Iași, 2013.

Pușcariu 1905 = Pușcariu, S. (1905), Etymologisches Wörterbuch der Rumänien Sprache, vol. I: Latenisches Element, Carl Winter's Universitätsbuchhandlung, Heidelberg.

REG II = Mareș, L. et. al. (1967), Lexic regional, vol. II, Ed. Științifică, București. REW = Lübke, W., M. (1924), Romanisches Etymologisches Wörterbuch, Fünfte Auflage, Carl Winter Universitätverlag, Heidelberg.

Rohlfs $2010=$ Rohlfs, G. (2010), Nuovo dizionario dialettale della Calabria, settima ristampa, Longo Ed., Ravenna.

Rohlfs 1968 = Rohlfs, G. (1968), Vocabolario delle Tre Calabrie, vol. II, III, Ed. Casa del Libro, Cosenza.

Scerbo 1886 = Scerbo, F. (1986), Dialetto calabro con dizionario, Arnaldo Forni Ed., Firenze.

Stancu 1995 = Stancu, I. et. al. (1995), Dicționar practic al limbii române, Ed. Floarea Darurilor, Bucureşti.

TLIO = Leonardi, L. et. al. (1997 - 2021), Tesoro della Lingua Italiana delle Origini [Online]. Available: http://tlio.ovi.cnr.it/TLIO/.

VEI = Prati, A. (1969), Vocabolario etimologico italiano, Multigrafica Ed., Roma. 